



\title{
CRÓWN-GALL OF ALFALFA
}

(WITH PLATES VII-X)

\author{
o. T. WILSON \\ UNIVERSITY OF WISCONSIN \\ PH. D. THESIS 1916
}


LIBRARY OF CONGRESS BECEIVED APR 61922 DOCUMENT'S L.V.S10

$\because \vdots$ 


\section{CROWN-GALL OF ALFALFA}

O. T. WILSON

(WITH PLATES VII-X)

Introduction

The crown-gall of alfalfa has been known in the United States for only a few years, the first published record of its occurrence in this country being in I909. It was at that time observed in California by Sмттн (32). Since then it has been reported from Arizona (23), Orégon (26), and Utah (27). It is probable that it also occurs in other western states. The disease has been known somewhat longer in other countries. PATOUILLARD and vON LAGERHEIM (28) in I895 published the earliest record of its occurrence in connection with an outbreak in Ecuador. In 1902 Magnus (2I) described the general features of the disease and recorded its presence in Germany. It has also been reported from England (29), and Italy, Sweden, and Switzerland (ro).

The lack of detailed information makes it difficult to estimate the economic importance of the disease. Old and powerful stands were killed in the fields of Ecuador (rg). Magnus considered the disease serious at Colmar in Alsace. Salmon (29) advised strict precautions against its spread in England. In the United States McCallum (23) reported the disease as serious but not widely distributed in Arizona at the time of his observations. Sмiтh noted it in only a few counties of California. According to O'GARA (26), many plants two to seven years of age were destroyed by the parasite in Oregon. In I9I5 resolutions were adopted by the American Phytopathological Society (3r) recognizing the serious possibilities of the disease and recommending its investigation by the government.

It is the purpose of this study to contribute to our knowledge of the life history of the causal organism.

\section{Material and methods}

Infected plants were secured from the vicinity of Medford, Oregon. In the winter of I9I3-I9I4 P. J. O'GARA sent specimens, 5I]

[Botanical Gazette, vol. 7o 
and in the fall of the year I9I4 material was received from Dr. M. P. Henderson. Other material was secured from alfalfa plants grown and infected in the greenhouse.

Standard histological and cytological methods were employed for the examination of the material; reference to these will be made in connection with various phases of the observations.

\section{Observations}

In I902 Magnus (2I) described the galls as branching tuberculate structures on the larger secondary roots of Medicago sativa. Upon examining cross-sections of the galls, he found large brown regions of irregular form, which proved to be cavities filled with resting spores of the parasite. "Thick-walled strongly encysted mycelium" was found in many of the cavities, but he did not find that the resting spores were attached to the hyphae. The amount of mycelium present in the different cavities varied; it was often entirely lacking. The hyphae were described as continuous or branched, and the protoplasm of the host cells was often completely displaced by these "wandering hyphae." Magnus thought that this mycelium might "awake to new life" after the winter resting period. He described the resting spores as spherical with one side flattened; he noted a colorless hyaline cell attached to the flattened side by means of a hyaline process. Many pores were found in the centers of the flattened walls of the spores. No other stages in the life of the parasite were mentioned by Magnus, and not all those described were figured. So far as the writer has been able to learn, no subsequent work has been published touching upon the life history of this organism, which has been classified as Urophlyctis alfalfae (von Lagerheim) Magnus. Figures of the galls have been published by various writers $(\mathbf{1} 3, \mathbf{2 2})$, and all agree with MAGNus' original description.

The alfalfa plants which furnished the material for these observations were several years old. Numerous galls corresponding to the structures described by MAGNus and others as the crowngall of alfalfa were found upon the plants (fig. I). Free-hand sections of such galls upon microscopic examination revealed numerous brownish resting spores, like those figuręd by MAGNUs, 
occupying irregular cavities in the tissues of the gall (fig. 8). If the spores are not scattered in sectioning they completely fill the cavities. They average $40 \mu$ in diameter. When shaken from the cavities they appear as a glistening brown powder.

With rare exceptions the spores are spherical in form, except for the depression on one side (fig. 8). Great irregularities of form may occur, especially near the borders of masses of spores, where the host tissues apparently interfere with the natural conformation of the spores. These irregular spores may conform to the outlines of the host cell occupied (fig. II). A group of slitlike pores in the depressed surface is normally a prominent feature of the spores (fig. 9). BALLy (3) observed similar pores in the walls of the spores of Urophlyctis Rubsaameni. The walls of the spores consist of two layers, the outer much heavier than the inner (fig. 6). The outer layer is yellow-brown, glassy in appearance, and brittle, as shown in sectioning. It is very resistant to stains, this quality being characteristic of resting spores of the Chytridiaceae. A positive reaction with phloroglucin indicates that it is lignified, but it does not stain with safranin. The inner layer of the wall is thin and hyaline in appearance; it responds to the zinc chloriodide test for cellulose. In this respect it is like the wall of the sporange of Olpidium Viciae described by Kusano (I7). It lacks the rigidity and brittleness of the outer layer. Ridges in the inner layer are of frequent occurrence (fig. I3).

In the resting condition the protoplasm of the unstained spore appears to be granular in nature and somewhat vacuolate (fig. Io). The nuclei cannot be distinguished without staining. Flemming's triple stain or Heidenhain's iron-alum-haematoxylin may be employed to bring out the nuclei. Many small nuclei are found to be scattered quite regularly through the cytoplasm of the spores (fig. I5). It is difficult to detect the structure of the nuclei at this stage; it becomes easier as the spore develops into a sporange. There is considerable variation in the response of the nuclei to stains. This is probably related to the difficulty in obtaining very thin sections through the spores. Nuclei which have been sectioned show that the chromatin is usually at the periphery, often concentrated at one side. In some preparations 
a nucleole appears clearly (fig. 24). The condition of the resting spore at this stage corresponds to that found by LOEWENTHAL (20) in the sporange of Olpidium Dicksonii at the very beginning of zoospore formation, when the presence of very numerous tiny nuclei was noted. Before staining, the content of the resting spore appears hyaline and refractive in section. Only the nuclei stain deeply; about each nucleus is a clear region, the clear portions being separated by lightly stained cytoplasm.

It is only in the resting stage that the heavy-walled bodies should be called spores. From the nature of their further development they are clearly potential sporanges. The resting spores of the Chytridiaceae have frequently been called sporanges.

The development of the sporanges was first studied in Van Tieghem cells, distilled water being the medium employed. The spores undergo an immediate change when placed in water. The granular appearance gives way to one in which the cell seems to be filled with small globules of oil. This indicates the first changes leading to the formation of zoospores. If the spores are crushed at this stage, numerous globules of fat are freed which stain with Sudan III or with osmic acid. As development continues, the fat globules in the sporanges apparently become larger and less numerous (fig. I4). This condition continues until the motile zoospores are set free.

In water the wall of the sporange also undergoes an almost immediate change; a swelling of the wall on that side takes place, presumably because of the entrance of water through the pores in the depressed surface. BüsGEN (5) observed a somewhat similar swelling of the wall in the sporanges of Cladochytrium Butomi. The sporanges become almost or quite spherical in outline. The pores become cracks, and after a time the outer layer may rupture as the inner content becomes more turgid (fig. I8). Various appearances are brought about by the protrusion of the inner layer of the wall and its contents. Sometimes the outer layer is thrown off like a cap, as BÜSGEN observed in his study of Cladochytrium. In the majority of cases, however, the outer layer remains intact. The whole process indicates a softening or gelatinization of the wall as compared with its previous brittle condition. 
Just before the exit of the zoospores a motion of the sporange contents is visible. The fatty globules are jostled about although they do not flow together. In a spore which is not viable the fat is frequently congregated into one or two large drops, but such a spore was never seen to develop into a sporange. The motion within the sporange is followed by the rupture or dissolution of the inner wall layer, allowing the zoospores to escape through the openings in the outer layer. The difficulty of observing their direct exit is enhanced by the fact that the porous side of the sporange wall is almost always downward in the hanging drop. The zoospores escape sometimes in groups, but usually singly. Often they seem to have difficulty in locating the pores, and they may swim about in the sporange for a considerable time or even disintegrate there (fig. I9). AtKinson (I) has observed an interesting amoeboid movement of zoospores within the sporanges of $R h i$ zophidium globosum just previous to their escape. Although no such amoeboid movements were seen at this stage in my material, the alternation of resting and active periods is a common occurrence, just as was observed by AtKinson.

In stained sections the development of the sporanges may be traced in a fairly complete series. Even in the very early stages each nucleus seems to be related to a definite portion of the cytoplasm (fig. 26). The nuclei have never been observed to occur in groups, but are rather uniformly distributed. As development continues, the nuclei decrease in number, as shown by the number present in a cross-section of a sporange. Apparently there is a disintegration of many of the small nuclei, while those which are to take part in the formation of zoospores increase in size. The structure of the latter nuclei also becomes much more clearly differentiated, and they stain with more uniformity (figs. 20, 27). The chromatin is now aggregated in knots connected by slender threads (fig. I6). In most of the preparations the connecting threads are not easily seen; in such cases one or more knots are apparent just within the nuclear membrane (figs. 20, 27); these large nuclei are the centers of zoospore formation. BARRETT (4) found in Olpidiopsis nuclei similar to those here described, which served as centers of zoospore formation. The transition stages 
from the condition shown in fig. I5 to that in which the spores are delimited have not been clearly followed. Zoospore formation is evidently a very rapid process. With the possible exception of the cilia, the zoospores are quite fully developed before their escape from the sporange. The vacuole and nucleus are quite well defined (figs. 23, 25). LOEWENTHAL (20) found a vacuole and well defined nucleus in the zoospore of Olpidium Dicksonii before its escape from the sporange. BARRETT observed the vacuole in the zoospore of Olpidiopsis, but apparently did not succeed in staining the nucleus. A cleavage of the sporange cytoplasm previous to zoospore formation is apparent in well stained sections. This cleavage begins at the margin of the sporange, and works toward the central region (fig. 22). The process apparently corresponds to that described by HARPER (I6) for Woroninella.

An interesting variation from this development is of quite common occurrence, but has been observed only in fixed and stained material, probably because it is masked in fresh material by peripheral fat globules in the sporange. Soon after the nuclei begin to enlarge in the stages preceding zoospore formation, one of them (sometimes several) undergoes an especially rapid development (figs. I7, 21), becoming separated from the other nuclei by a surrounding portion of denser cytoplasm. This is often quite clearly shown, even in unstained sections. A spore may be clearly delimited about this nucleus, while the other spores are yet in an early stage of development. This spore is much larger than the others formed in the same sporange. All the zoospores are alike in structure, the only marked variation being in size. The formation of several of the large spores in the same sporange is exceptional (fig. 29).

When freed in water, the zoospores exhibit a great variety of movement. Often the long cilium, which is quite clearly visible, seems to impede the movement of the zoospore, which exhibits a violent jerking motion. Irregular gyrations are common. Frequently a zoospore moves back to the sporange from which it escaped and seems to seek an entrance. At times the zoospores move very rapidly from the field of observation in a direct line. The movements become less vigorous after a time; the ellipsoid 
or ovoid changes to a spherical form, and the long cilium becomes more plainly visible than before, dragging behind passively. This last described feature has been reported for the motile spores of various Chytridiaceae. Periods of activity alternate with periods of passivity, during which the vacuolated condition is very evident. The fat drop is visible only during the active periods. BARRETT (4) and ButLer (6) have observed pulsations of the vacuoles in the spores of Olpidiopsis at this stage.

The fat drop is the most prominent internal feature of the active zoospore. It may be seen to shift rapidly when the zoospore is in motion. After a period varying from a few minutes to several hours, terminated by sluggish amoeboid movements, the zoospore comes to a final rest and soon disintegrates. It seems likely that the refractive body so commonly observed in the zoospores of the Chytridiaceae is a drop of fat occupying a vacuole. ATKInson (2) observed the presence of a prominent fat drop in the zoospore of Rhizophidium brevipes.

Amoeboid movements of zoospores have frequently been mentioned by investigators of the Chytridiaceae. ScHenk (30) observed this phenomenon as early as I858. DANGEARD (8) noted that the zoospores of Chytridium xylophilum creep like amoebae. BüsGEN (5) observed similar movements in his study of Cladochytrium Butomi.

I did not directly observe the exit of the large zoospores from the sporanges, but they were seen in considerable numbers moving slowly about in the water, remaining close to the sporanges from which they had emerged. The content of these large zoospores appears to be more granular than that of the smaller ones, which latter appear hyaline in water. Very soon after their exit the large zoospores are surrounded by the smaller ones. One or several of the latter move swiftly toward a large zoospore and become attached to it. As many as five small zoospores have been seen adhering to one large spore, but in all cases only one remains attached. There seems to be no uniformity as regards the point of attachment. The small zoospore which remains attached loses its cilium just at the time of contact. KUSANO (I 7 ) reported a resorption of the cilium at this stage in Olpidium. After a small 
zoospore has become permanently attached to a large one, the latter continues to move about for a time before coming to rest. An amoeboid form is finally assumed, and disintegration soon follows.

Fusion of zoospores has been reported but rarely in the Chytridiaceae. Probably this is because of the very limited observations upon the motile stages. Fiscr (I4) observed and figured a fusion of zoospores for Reesia amoeboides. DANGEARD (9) noted an apparent fusion in Sphaerita endogena. KusANo observed a clear case of fusion in Olpidium, the fusing cells being similar in size. The observations of SOROKIN (33) upon Tetrachytrium, of AtKinson (2) upon Lagenidium, and of von LAgerheim (I8) upon Rhodochytrium should also be mentioned in this connection.

The motile spores were fixed and stained upon the cover slip by the use of osmic acid and gentian violet. Each spore was found to have a short cilium as well as the long one visible in the water (fig. 28). The motion of the zoospore, after the long cilium becomes passive, is probably due to the activity of the shorter cilium. It seems possible that the uniciliate condition is not so common among the Chytridiaceae as has been thought. Care in staining and observation is necessary for a successful determination of the number of cilia. CORNU (7) found only one cilium borne by the motile spore of Olpidiopsis. FISCHER (I5) later found two, which observation was confirmed by BARRETT (4): Cilia of unequal length on the same zoospore have been reported and illustrated for various members of the family, as for example Sphaerita endogena (9).

The cilia of the motile cells of the organism under consideration are attached at the same end of the zoospore to what seems to be a platelike thickening of the membrane. The manner of attachment is much more clearly seen in the larger zoospores (figs. 31, 32). The oil vacuole is near the place of attachment of the cilia (fig. 40). The nucleus lies back of the vacuole, imbedded in the cytoplasm. From the cilia to the nucleus there is a connecting, coneshaped, apparently fibrous structure, which extends through the vacuole (figs. 31,32 ). Fig. 25 shows a general similarity to the zoospore structure described by LoEWENTHAL (20) for Olpidium, and figured by Nownowsi (25) for Polyphagus Euglcnac. 
Fusion stages may be quite clearly followed in material fixed and stained on the slide. Fig. 28 shows two zoospores, a large one and a small one, apparently in the same condition as when freed from the sporange (see fig. 30). The nuclei of stained zoospores often appear to be within a vacuole because of their position when fixed to the slide. The larger zoospore, either before or at the approach of the smaller one, may put out one or more projections in the direction of the latter (fig. 33). Fusion may take place at the apex of such a projection (figs. 34, 36). The two nuclei may be seen within the larger body following the fusion (fig. 35). The fusion of the nuclei has not been observed. Figs. 37 and 38 possibly indicate stages following a fusion succeeded by a division of the fusion nucleus. Many small nuclei appear in the body of the organism at this stage (fig. 37), and there is some evidence of a cell multiplication by budding (figs. $38,44,5 \mathrm{I}$ ). It is entirely possible, however, that a multiplication of the nuclei in either the large or the small motile bodies may occur without any nuclear fusion. The observations at this point do not justify very definite conclusions, since the staining of the zoospores in toto makes the following of the nuclear phenomena decidedly difficult. There seem, however, to be some grounds for maintaining that the phenomena just described constitute a true case of heterogamy. One cell is characterized by a large body, slow movements, and a nucleus of average proportional size. On the other hand, the smaller cells are swift of movement and have nuclei very large in proportion to their size. The oil drop probably serves as reserve food for the temporary nutrition of either gamete in case fusion does not occur, or of the zygote in case it does occur.

In order to secure the development of the zoospores upon the host, young alfalfa seedlings were carefully washed and introduced into small vessels containing sterile distilled water, so that only the roots and the lower parts of the stem were immersed. A gall from an infected plant was carefully washed, crushed, and introduced into the water. After one day the seedlings were removed from the water, crushed under cover slips on slides, and examined for evidence of the presence of the parasite. On and in the tissues of the host which had been at the water level were numerous 
amoeboid bodies, as well as zoospores that still retained their characteristic form. The cilia, however, were no longer to be seen. The amoeboid bodies were watched for some hours and were seen to become clustered and to move in masses; they could also be seen to bud at times, much as in the case of the ciliated cell shown in fig. 38. Budding of the amoebae in the infection stage has been reported to occur in Plasmodiophora (II). Seedlings left under these conditions developed small galls at the bases of the secondary roots.

To secure stained preparations of the plasmodium in its early stages, young alfalfa seedlings were grown in a pot in which a badly infected mature plant was also growing. At various times seedlings were removed and examined. Small galls were soon found at the bases of the secondary roots of some of the seedlings. As soon as the plants began to produce crown buds, galls appeared upon the crown (fig. 3). These young galls were fixed, imbedded, sectioned, and examined after various staining processes. The plasmodium of the parasite was found to be widely extended in the galls. An amoeboid or plasmodial vegetative condition of the parasite within the host has often been noted in members of the Chytridiaceae. Fischer (I5) and BARRETt (4) have observed it in species of Olpidiopsis. CORnu (7) observed it, as well as the amoeboid movement of the zoospores, in various members of the family. He also noted a suggestion of cleavage in what he called the plasmodium of Rozella, and suggested its formation by the union of many amoeboid zoospores. Fischer went so far as to classify several genera upon the basis of differences in the plasmodia. He observed that the protoplasm of the parasite mingled intimately with that of the host and gradually displaced it. FIsch's (I4) description of Reesia amoeboides is a striking suggestion of the near relationship of the group to the Myxomycetes. A secondary infection of cells occupied by the plasmodium is of common occurrence. As a result, the cells of the galls are often occupied, not only by the plasmodium, but also by the earlier stages of the parasite (figs. 39, 4I).

The nuclei in the plasmodium are very numerous, corresponding quite closely in size and appearance to those in the resting spores 
(figs. 42, 43, 45). The central ciear portion surrounded by peripheral chromatin is characteristi: of their appearance, although in many cases the whole nucleus iakes up the chromatin stains. The cytoplasm of the plasmodium is slightly granular and stains very lightly. It has not yet been possible to keep the plants infected in the greenhouse long enough to secure the development of the resting spores within the galls.

In order to examine the plasmodia in older galls, sections were stained with the triple stain and with haematoxylin. Only comparatively young galls nere sectioned, as considerable foreign mycelium was found to be present in the older galls. Infection by other fungi, and the consequent presence of a foreign mycelium which has no connection with the organism causing the galls, is to be expected because of the contact of the infected parts with the soil. Sections of smooth intact galls showed no such signs of foreign contamination. The same type of plasmodium, however, that was found on the exterior of seedlings exposed to infection, and within the tiny galls formed upon seedlings grown in infected soil, was also found throughout the cells of the galls containing resting spores. In marginal cells of some galls the amoeboid cells were found in numbers (fig 47 ), preceding the formation of a plasmodium such as is shown in fig. 5 .

In some cases the plasmodium forms an irregular streaming mass, forcing its way through and between the cells of the gall tissue (fig. 45). In other cases it ramifies through the cells as a network of naked protoplasm (fig. 42). Multiplication of the plasmodia may occur in these stages by budding and fragmentation (fig. 5I). The walls of the host cells are often dissolved or gelatinized in advance of the main body of a plasmodial mass, presumably by enzymatic action (fig. 4).

The resting spores are formed in cavities or pockets occupied by the parasite. Remains of host walls are mingled with the plasmodial masses of the parasite, and a clear staining of the material at this stage is almost unattainable. A yellow coloration pervades the unstained content of the pockets previous to the formation of the spores. At the time of spore formation the yellow coloration is limited to the outer walls of the spores, their content being 
clear and refractive. Just how the formation of the spores takes place has not been determined.

Around the margins of the larger cavities containing spores the naked protoplasm of the plasmodium may be found in a more or less shrunken condition. The similarity of this protoplasm to that within the spores is convincing evidence of the origin of the spores from the plasmodium, the most noticeable difference being in the more regular arrangement of the nuclei within the spores. Isolated host cells or groups of cells may be occupied individually by separate plasmodia; it would seem that these small plasmodia may develop walls about themselves and become resting spores. The subject of spore formation is in need of very careful and prolonged investigation.

Primary infection, the actual entrance of the parasite into an uninfected host, has not yet been observed. The fact that the parts invaded are the adventitious buds and the secondary roots in the very earliest stages of development minimizes the chances of such an observation. There is little doubt, however, that either the zoospores before fusion, the zygotes, or the plasmodia formed on the surface of the host may penetrate the embryonic host tissues. In young bud galls cases have been found in which practically every cell of the growing tip was occupied by the parasite (fig. 7). From this figure it will be seen that the infecting cells of the parasite vary greatly in form and size after penetration. Often they are found in contact with the host nucleus, the latter being still intact. Sometimes a host cell contains several of the invading cells. Sometimes a fusion of a number of these invading cells, preparatory to the formation of a larger plasmodium and the breaking down of the separating host cell walls, may be noted. All these features are illustrated in fig. 7 .

The discussion of the studies upon the life history of the parasitic organism may be concluded by a brief reference to the subject of nuclear divisions in the different stages. Had division figures not been found, identification of the nuclei in the plasmodium would have been questionable, since these nuclei are very small and details of their structure are not easily distinguished. Dirision figures, however, are very common in some of the prepara- 
tions, and are easily recognized as such upon careful examination. The process of division is clearly mitotic (figs. 46, 48-50, 53-57). Dark bodies suggesting centrosomes are commonly visible in the metaphases at the poles of the spindles (figs. 46, 50). The early divisions of the nuclei in the amoeboid infection stages have been followed with only partial success. The figures correspond to those seen in the later divisions, but average considerably larger (fig. 44). The centrosomes, if the dark bodies at the poles of the spindles are to be called such, are a constant feature in good preparations. Clearly recognizable division figures within the sporange have been found less frequently. There is some evidence that a division occurs while the nuclei are yet very small (fig. I5), and much better evidence of a division just preceding the formation of zoospores (figs. I7, 48). Whether these are in the nature of reduction divisions must be left for future determination. Careful study has failed to lead to a definite conclusion as to the chromosome number. In the divisions immediately preceding the formation of the zoospores the number of chromatic bodies seen is apparently four (fig. 48). In all the division figures observed, at whatever stage, the spindle seems to be intranuclear, corresponding to the findings of other investigators of members of the Chytridiaceae.

\section{Classification of parasite}

Von Lagerhen $(\mathbf{I 9}, 28)$, who first noted the occurrence of the crown-gall of alfalfa, classed it in the genus Cladochytrium with the specific name alfalfae. MaGnus (2I), in his article of 1902, gave strong reasons for removing the organism from that genus and referred it to the genus Urophlyctis, retaining the specific name given by vON LAGERHEIM. The terminology Urophlyctis alfalfac (von Lagerheim) Magnus has been generally accepted in later works. Although MAGnus was right in removing the parasite from the genus Cladochytrium, it is doubtful whether he was justified in placing it in the genus Urophlyctis, on the basis of his limited observations. The description of the genus Urophlyctis as given in Saccardo's Sylloge Fungorum (7: p. 303) is as follows:

Urophlyctis Schroet. Krypt. F1. Schles. Pilze. p. I97. (Etym. oura cauda et plilyctis bulla.) Zoosporangia sessilia in plantis vivis, fasciculis filamentorum 
immersa. Sporangia perdurantia intra cellulas plantarum viventium e mycelio filiformi perforatas formata, copulatione cellularum similium orta. Cellulae alterius protoplasma in alteram effunditur, haec vero crescit et membrana crassa cincta in sporangium perdurans mutatur.

'The studies of the alfalfa crown-gall organism by MAGNus did not establish the characters cited by SACCARDO. The descriptions of the genus as given by ENGLER and PRANTL (I2) and by MiguLA (24) also include characters that MAGNus apparently did not verify.

The writer has failed to observe, in the organism studied, the characters ascribed to the genus Urophlyctis. In view of the incompleteness of the results, no change of classification is suggested at the present time. It seems highly desirable, however, that careful investigations be made of the various organisms referred to this genus. Possibly it may prove necessary to discard some of the previously used diagnostic characters and to redescribe the genus on the basis of fuller observations. The relationships of the Chytridiaceae are in an unsettled state. There have been many suggestions in the literature that would lead one to question whether or not this family finds its proper place among the Phycomycetes. The studies upon which classification has been based in many cases have been very superficial, and few efforts have been made to follow out complete life histories. Cases in which an amoeboid or plasmodial stage has been noted, with the absence of anything resembling mycelium excepting naked threads of protoplasm, furnish reason to suspect that the family is more closely related to the Myxomycetes than to the Phycomycetes.

\section{Summary}

I. The resting spores, placed in water cultures, develop into sporanges.

2. Within these sporanges are formed motile zoospores of two sizes; frequently one large zoospore and many small ones are formed in the same sporange.

3. One or several small zoospores may become attached to one large zoospore. Only one remains permanently attached. There is some evidence that this attachment is related to a sexual fusion.

4. The movement of the large zoospore continues after the attachment of the small one. 
5. The small zoospores, the large zoospores, and the united zoospores (zygotes?) become amoeboid after a period of motility.

6. In the amoeboid state, singly or in groups, these bodies may be observed upon the surface of the host.

7. In infected soil young alfalfa seedlings develop galls in which plasmodia are found.

8. In older galls similar plasmodia are found, which ramify through the tissues of the gall.

9. The resting spores are formed in cavities within the tissues of the galls.

ro. The cytoplasmic and nuclear contents of the resting spores in the dormant condition correspond to those of the plasmodium in the stage immediately preceding the formation of resting spores.

University of Cincinnati

Cincinnati, OHio

\section{LITERATURE CITED}

r. Atkinson, G. F., Intelligence manifested by swarm-spores of Rhizophidium globosum. Вот. Gaz. 19:503-504. I894.

2. - - Some fungous parasites of algae. Bот. GAz. 48:32I-338. I909.

3. Batly, W., Cytologische Studien an Chytridineen. Jahrb. Wiss. Bot. 50:95-I 53. I9II.

4. Barretr, J. T., Development and sexuality of some species of Olpidiopsis. Ann. Botany 26:209-238. I9I2.

5. BüsGen, M., Beitrag zur Kenntnis der Cladochytrieen. Cohn's Beiträge zur Biologie der Pflanzen 4:269-283. I887.

6. Butler, E. J., An account of the genus Pythium and some Chytridiaceae. Memoirs Dept. Agric., India, Botanical Series I:I-I60. I907.

7. Cornu, M., Chytridinées parasites des Saprolegniées. Ann. Sci. Nat. Bot. V I5:II2-I98. I872.

8. Dangeard, P. A., Recherches sur les organismes inférieurs. Amn. Sci. Nat. Bot. VII 4:24I-34I. I886.

9. - - Mémoire sur les parasites du noyau et du protoplasm. Le Botaniste 4:I99-23I. I894-I 895 .

ro. Delacrotx, G., and Maublanc, A., Maladies des plantes cultivées. II. Maladies parasitaires, p. 78. Paris. I 909.

Ir. DugGar, B. M., Fungous diseases of plants, p. I40. I909.

12. Engler, A., and Prante, K., Die natürlichen Pflanzenfamilien, $\mathrm{I}^{\mathrm{I}}$ : Leipzig. I897.

13. ERIKSSon, J., Fungoid diseases of agricultural plants. MIolander's translation, p. 3०. I9I2. 
I4. Fiscir, K., Beiträge zur Kenntnis der Chytridiaceen. Berlin. I884.

15. Fischer, A., Untersuchungen über die Parasiten der Saprolegnieen. Jahrb. Wiss. Bot. 13:286-37I. I882.

r6. HARPER, R. A., Cell division in sporangia and asci. Ann. Botany I3:467-525. I 899 .

I7. Kusano, S., On the life-history and cytology of a new Olpidium. Jour. Coll. Agric. Imperial Univ. Tokyo 4:I4I-I99. I9I2.

I8. VON LAGERHEIM, G., Rhodochytrium nov. gen., eine Uebergangsform von den Protococcaceen zu den Chytridiaceen. Bot. Zeit. 51:43-5I. I893.

I9. - Mykologische Studien. I. Beiträge zur Kenntnis der parasitischen Pilze, r. Über eine neue Krankheit der Luzerne (Medicago sativa L.). Bihang K. Svenska Vet. Akad. Hand. 24: no. 4. 1898.

20. Loewenthal, W., Weitere Untersuchungen an Chytridiaceen. Archiv für Protistenkunde 5:22I-239. I905.

2r. Magnus, P., Über die in den knolligen Wurzelauswuchsen der Luzerne lebende Urophlyctis. Ber. Deutsch. Bot. Gesells. 20:29I-296. I902.

22. Massee, G., Diseases of cultivated plants and trees. London. I9io.

23. McCallum, W. B., Report of the botanist. Ariz. Agric. Exp. Sta. Rept. 20:583. I909.

24. Migula, W., Kryptogamen-Flora von Deutschland, Deutsch-Oesterreich und der Schweiz, $3^{\mathrm{r}}$ : Gera. I9I0.

25. Nowakowski, L., Polyphagus Euglenae. Cohn's Beiträge zur Biologie der Pflanzen 2:20I-219. I877.

26. O'GARA, P. J., Urophlyctis alfalfae, a fungous disease of alfalfa occurring in Oregon. Science N.S. $36: 487-488$. I912.

27. - - Existence of crown-gall of alfalfa caused by Urophlyclis alfalfae in the Salt Lake Valley, Utah. Science N.S. 40:27. I9I4.

28. Patoulllard, N., and Lagerheim, G., Champignons de l'Equateur. Bull. Herb. Boissier 3:53-74. I895.

29. Salion, E., Urophlyctis alfalfae, a fungous disease of lucerne in England. Gardener's Chronicle 39:122-123. I906.

30. Schesk, A., Über das Vorkommen contractiler Zellen im Pflanzenreiche. IVürzburg. I 858 .

3I. Shear, C. L., Report of the secretary-treasurer, sixth annual meeting of the American Phytopathological Society. Phytopathology 5: r28-I32. 1915 .

32. Sirtri, E. H., A note on Urophlyctis alfalfae (v. Lagerh.) P. Magnus in California. Science N.S. 30:2II-2I2. I909.

33. Sorokix, N., Einige neue Wasserpilze. Bot. Zeit. 32:305-315. I874.

\section{EXPLANATION OF PLATES VII-X}

With the exception of plate VII, the figures were drawn with the aid of an Abbé camera lucida at table level. Leitz oculars and objectives were used, giving the magnifications indicated. 


\section{PLATE VII}

FIG. I.-Alfalfa plant badly infected with crown-gall; $\times \frac{1}{2}$.

F1G. 2.-Single galls; $X_{\text {I. }}$.

FIG. 3.-Seedling infected in greenhouse, galls beginning to develop at crown; $X \mathrm{I}$.

FIG. 4.-Section showing action of parasite upon walls of host cells in advanced stage; parenchyma tissue; $\times_{3} 00$.

FIG. 5.-Plasmodium on border of gall; $\times 300$.

FIG. 6.-Sections of resting spores showing outer and inner layers of wall; $\times$ I30.

FIG. 7.-Section of young gall on seedling showing cells of parasite in host cells; some of former fused into tiny plasmodia, others in contact with host nuclei; $\times_{300}$.

FIG. 8.-Section of gall showing cavities and resting spores of parasitc.

\section{PLATE VIII}

FIG. 9.-Unstained resting spore, view of hollowed surface; $X_{750}$.

FIG. IO.-Unstained resting spore, side view; $\times 750$.

FIG. II.-Resting spore conforming to host cell in which it has developed; $\times 750$.

FIG. I2,-Unstained resting spore showing marginal vacuoles; $\times 750$.

FIG. I3.- Irregular relation of walls of resting spore; $X_{I} 800$. $\times 750$.

FIG. I4.-Unstained sporange when first put into hanging-drop culture;

FIG. I5.-Section of resting spore; may be stage just following resting period; $\times \mathbf{I} 800$.

FIG. I6.-Group of nuclei in sporange; chromatin in marginal aggregations; $\times I 800$.

FIG. I7.-Division figures in sporange, apparently just preceding zoospore formation; large nucleus destined to be nucleus of large zoospore; $X_{1} 800$.

FIG. I8.--Spore formation about completed, unstained; note rupture of outer wall; $\times 750$.

FIG. I9.-Unstained sporange containing a few zoospores; most of those formed already escaped through prominent opening; $\times 750$. XI800,

FIG. 20.-Section of sporange just preceding formation of zoospores;

FIG. 2I.-Section of sporange showing large nucleus which will be included in large zoospore; $\times 1800$.

FIG. 22.-Marginal portion of sporange showing beginning of cleavage into zoospores; $X I S 00$.

FIG. 23.-Zoospores almost fully formed in sporange; $X I S 00$.

FIG. 24. -Nuclei of sporange showing nucleoles; $X I 800$.

FIG. 25.-Zoospore just before exit from sporange; $X I S 00$.

FIG. 26.-Nuclei of resting condition of spore. 
FIG. 27.-Section of sporange dividing into zoospores; note characteristic arrangement of chromatin in knot at one end or side of nucleus; $X_{1} 800$.

PLATE IX

FIG. 28.-Free zoospores of two sizes; $X_{I} 800$.

FIG. 29.--Group of large zoospores formed in same sporange; $X_{\mathrm{I}} 800$.

FIG. 30.-Large and small zoospore within same sporange; $X I 800$.

FIGS. 3I, 32.-Two large zoospores; $\times$ I800.

FIG. 33.-Large and small zoospore showing projection of former toward latter; position may be accidental; $\times 1800$.

FIGS. 34, 36.-Attachment of small zoospores to large; $X_{I} 800$.

FIG. 35.-Binucleate zygospore following fusion(?); $\times \mathrm{I} 800$.

FIG. 37.-Amoeboidal stage following fusion, or perhaps developing without fusion; nuclei have multiplied; $\times$ I 800 .

FIG. 38.-Apparent budding in amoeboid stage; $\times I 800$.

FIGS. 39, 4I.-Plasmodium and young infecting amoebulae in same host cells; $\times I 800$.

FIG. 40.-Free zoospore, small size; $X_{\mathrm{I}} 800$.

PLATE $X$

FIG. 42,--Plasmodium spreading through tissue of host; host nucleus visible; $X$ ISoo.

FIG. 43.-Plasmodium breaking through wall of host cell; $\times$ I80o.

FIG. 44.-Amoebulae within tissues of host; note nuclei in division; $\times I 800$.

FIG. 45.-Note as for fig. 42 ; no host nucleus visible.

FIG. 46.-Nuclei of plasmodium in division; $\times \mathrm{I} 800$.

FIG. 47.-Amoebulae massed in marginal cells of gall; $X_{1800}$.

FIG. 48.-Division figures in sporange; $\times 1800$.

FIG. 49.-Prochromosomes(?) in nuclei of sporange; $X_{I} 800$.

FIGS. 50, 53.-Anaphases in plasmodium; $\times 1800$.

FIG. 51.-Budding or fragmentation of plasmodium; $\times$ I800.

FIG. 52.-Nuclei of sporange just preceding formation of spores; $\times \mathrm{I} 800$.

FIGS. 54-57.-Division figures in plasmodium within host; $X_{1800}$. 

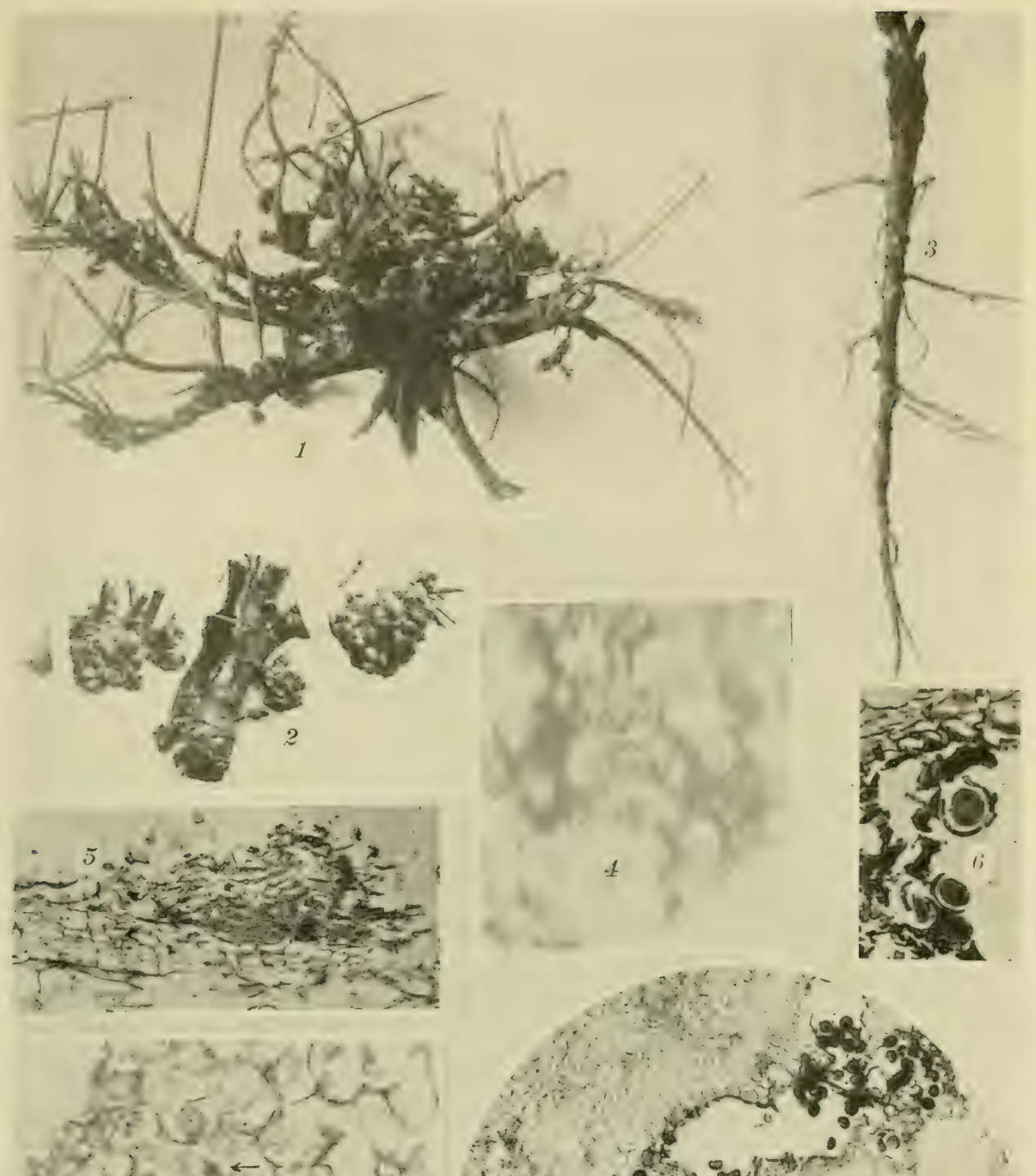

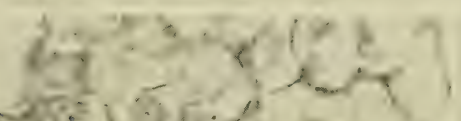

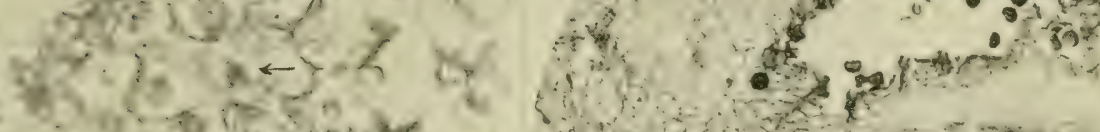

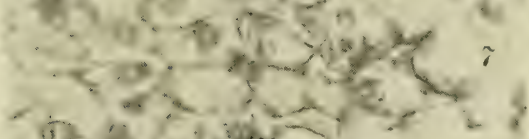

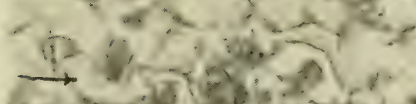

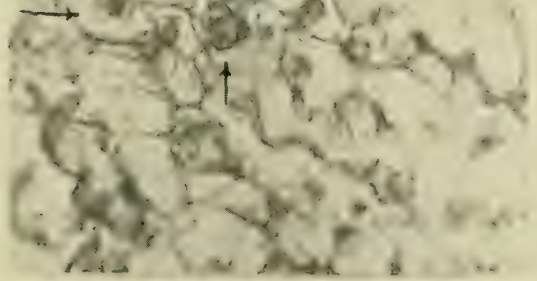

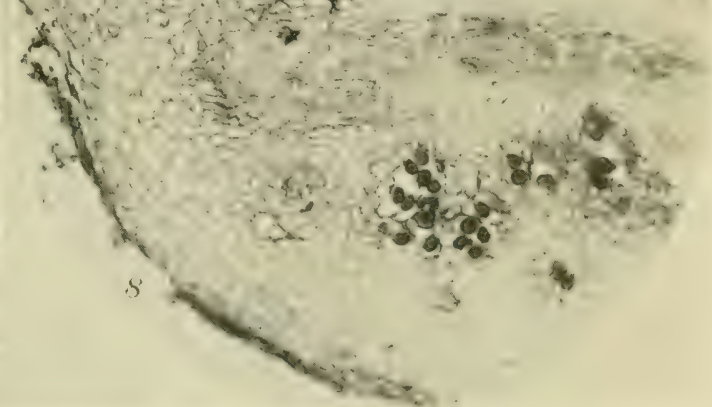



BOTANICAL GAZETTE, LXX
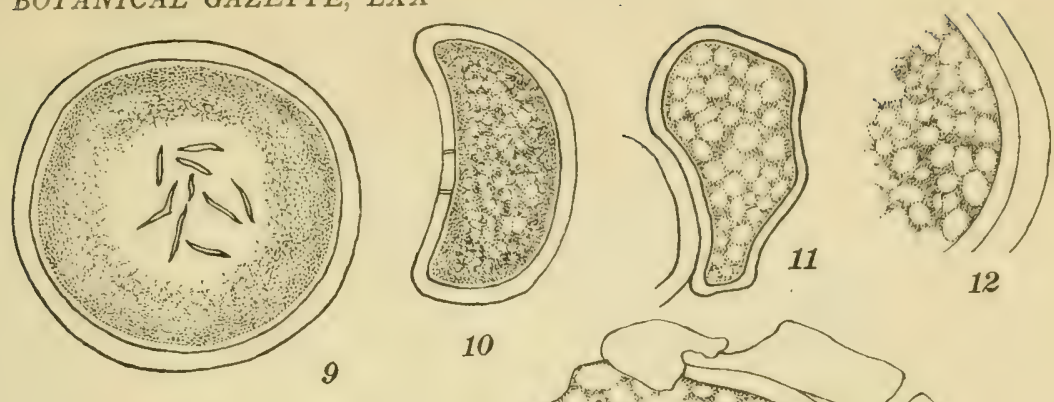

PLATE VIII
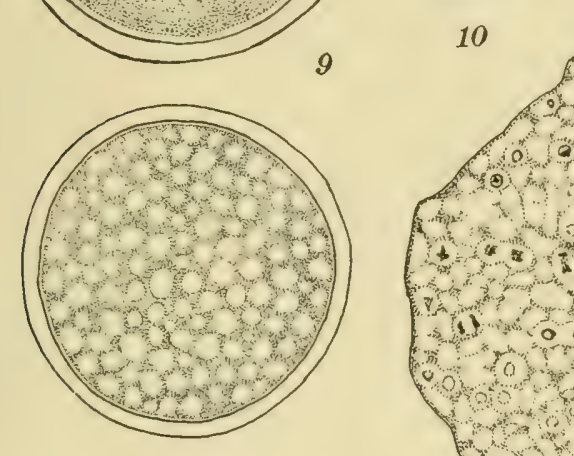

12
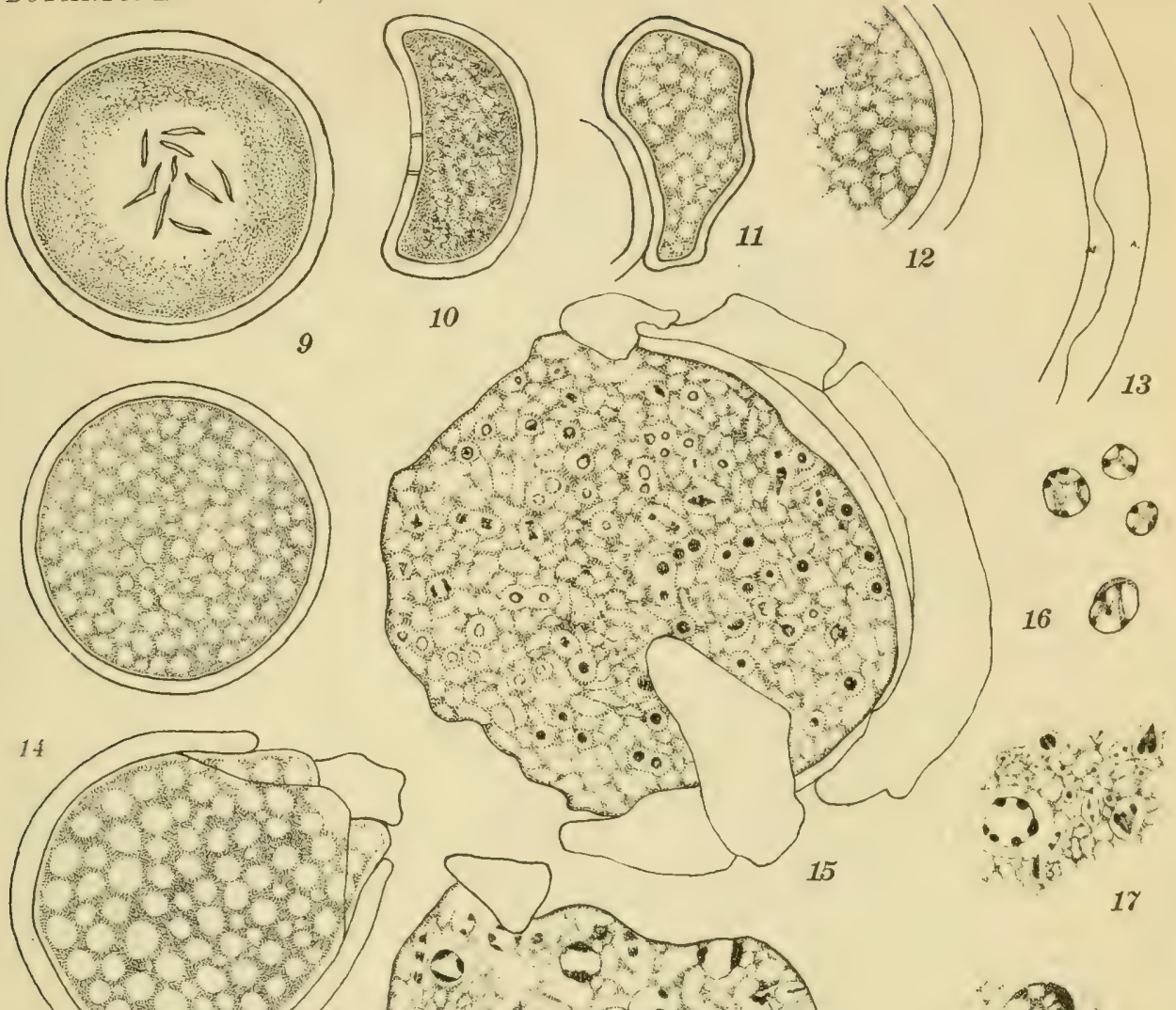

18
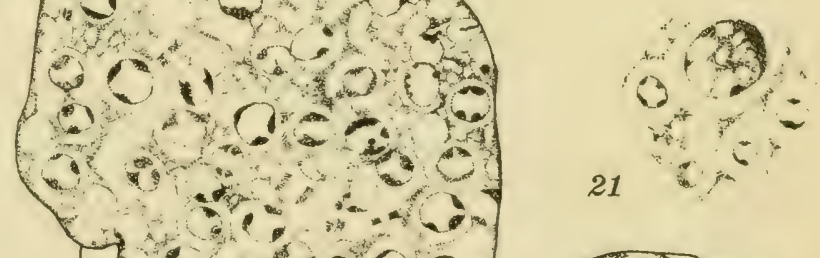

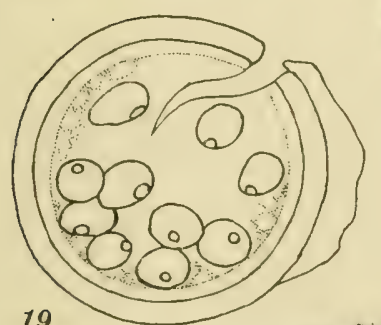

19

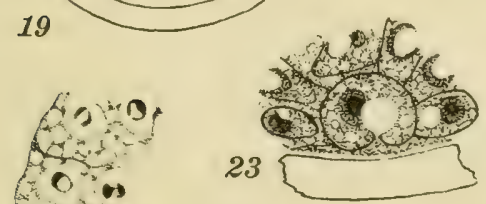

$x=?$
$x_{0}$

22

20
324
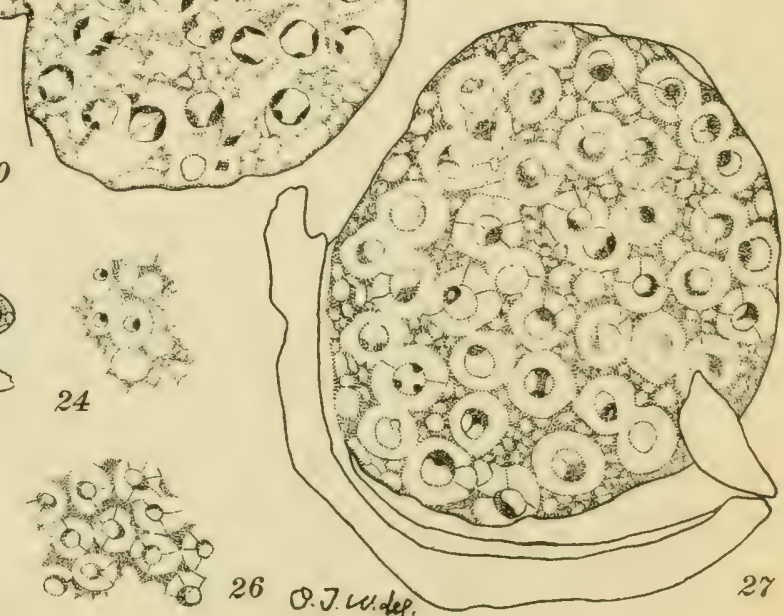

IVILSON on CROWN-GALL 


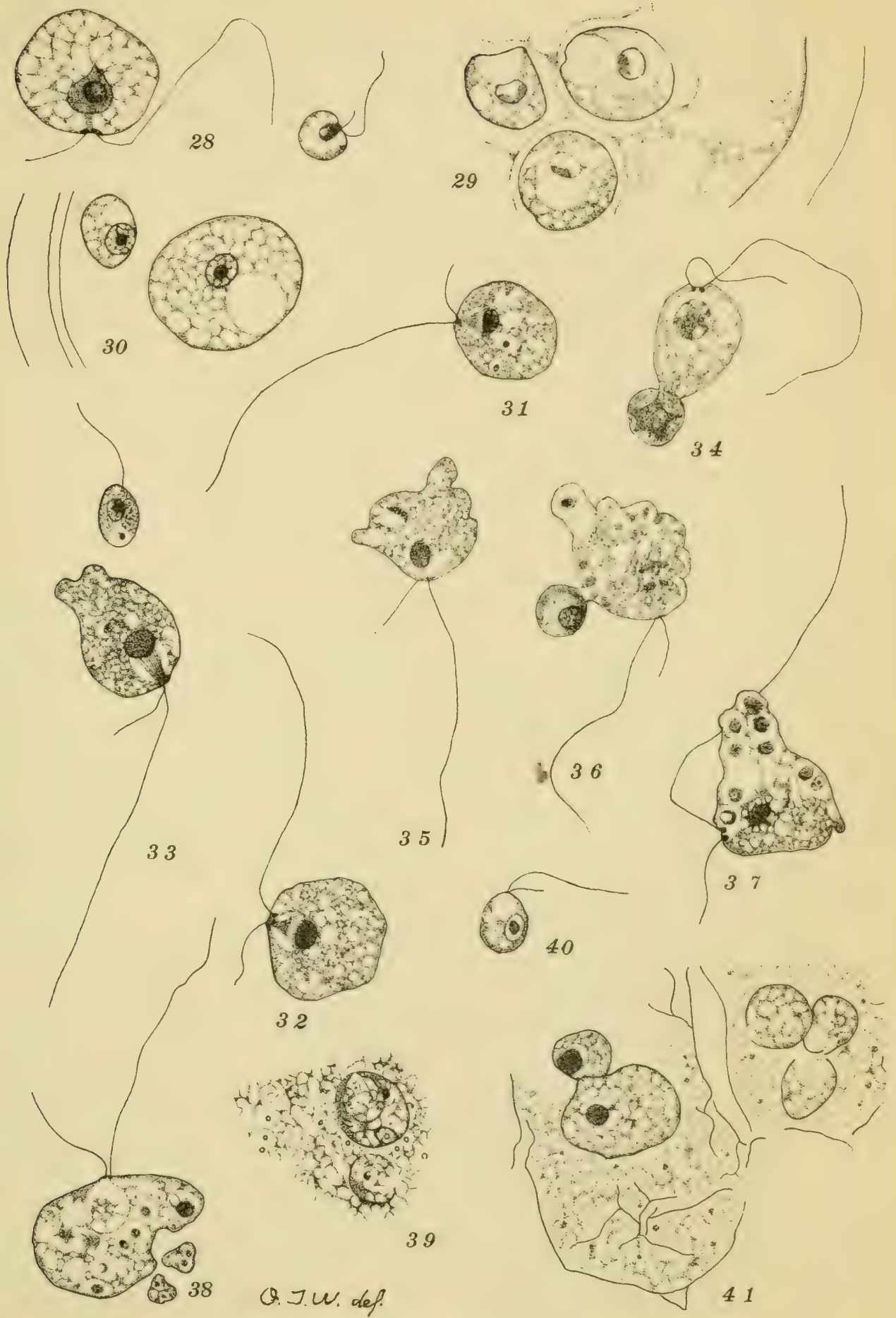

WILSON on CROWN-GALL 


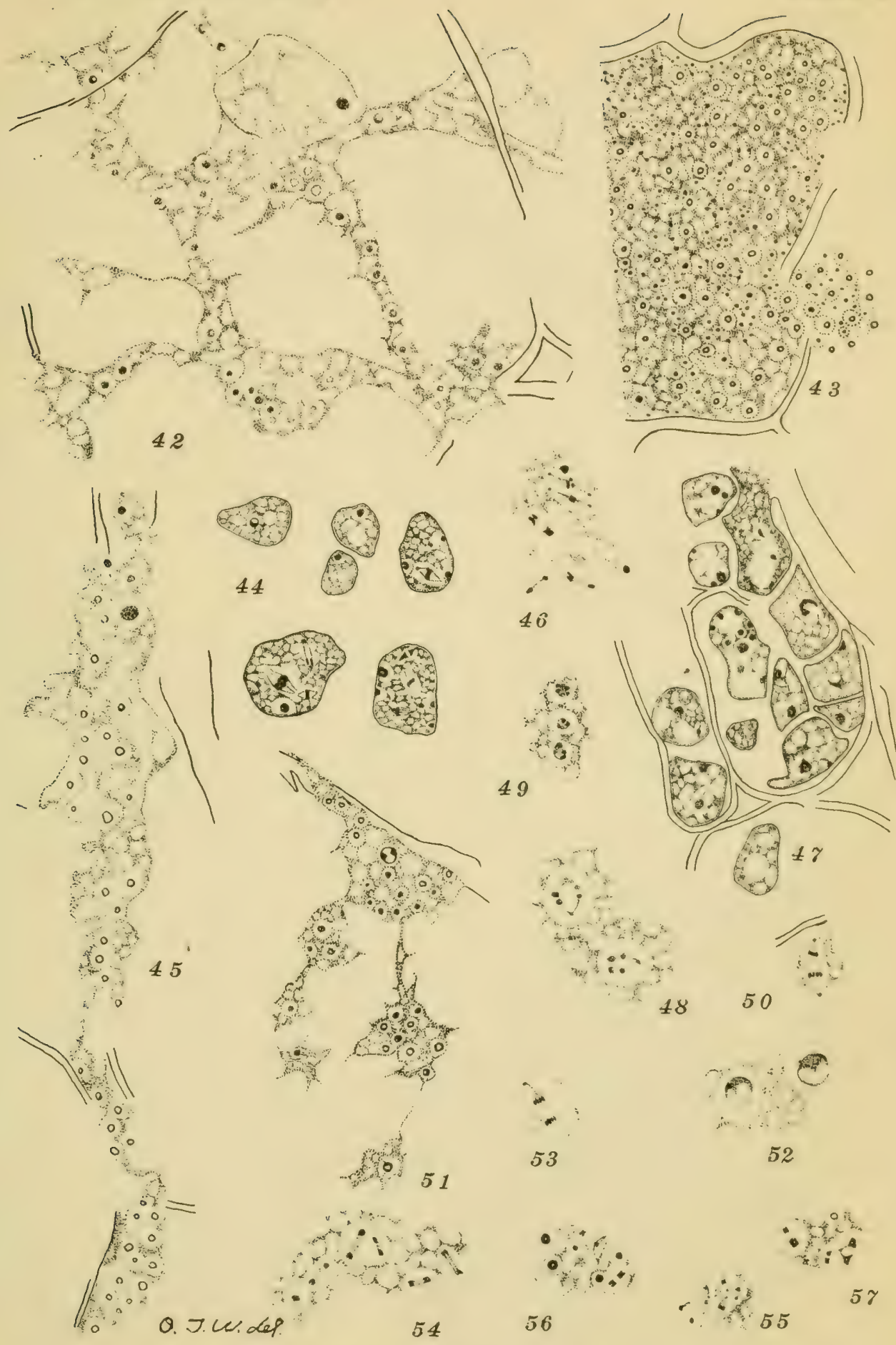

LIBRARY OF CONGRESS

(I)

00214894932 